\title{
Romanian de fapt - from adjectival adjunct to attention marker
}

\section{Cezar Bălășoiu}

University of Bucharest

cezar.balasoiu@ litere.unibuc.ro

How to cite: Bălăşoiu, Cezar. 2021. Romanian de fapt - from adjectival adjunct to attention marker. Isogloss. Open Journal of Romance Linguistics 7, 12: 1-31.

\section{Abstract}

This research traces back the development of the Romanian phrase de fapt ('in fact, actually, indeed'), based on written and oral corpora. De fapt has been attested in Romanian since late $19^{\text {th }}$ century; chronologically, it is the last of the three Romanian adverbial expressions (alongside $\hat{\imath}$ faptă and $\hat{\imath}$ fapt) that went through all the stages of the grammaticalization cline proposed by Elizabeth Traugott for this type of adverbs. However, we consider that this phrase actually goes even further by becoming, in press headlines, an attention marker (Fraser 2009: 297), thus joining the category of să vezi ce $s$-a întâmplat ('you won't believe what has happened'). Thus, in press titles such as $C u$ ce femeie a petrecut aseară Pepe, de fapt ('Who is the woman Pepe actually spent the evening with'), de fapt loses its contrastive discourse marker rhetorical function of contrasting with a previous element and acquires a new function, i.e. of inviting the reader to read a story that (s)he would have otherwise overlooked. In this type of occurrences, de fapt acquires, for the first time, an intersubjective value.

Keywords: pragmatic markers; discourse markers; attention markers; weasel words. 


\section{Preliminaries}

In recent decades, discourse markers (DM) have been constantly addressed to by the specialised literature. Alongside general works that dealt with this topic, such as Schiffrin 1987, Lenk 1998, Traugott \& Dasher 2002 or Fraser 2009, several specific DMs have been thoroughly analysed from different perspectives. For example, the French forms de fait, en fait, au fait, en effet (Danjou-Flaux 1980; Rossari 1990, 1992a, 1992b; Blumenthal 1996; Savelli 2001; Forsgren 2009; Saunier 2017; Wandel 2017), the English in fact and actually (Oh 2000; Taglicht 2001; Mladenovici Ionescu 2020) and the Italian infatti (Brutti 1999; Sergo 2015), to quote just a few, have been synchronically examined (and subject to an intralinguistic comparison on several levels). They were also diachronically approached, so as to check the hypothesis proposed by Traugott 1982 or Traugott 1997 related to the grammaticalization and pragmaticalization of several adverbs, while also highlighting the particularities of their evolution, (in fact: Traugott 1997, 1999; Schwenter \& Traugott 2000; Traugott \& Dasher 2002, de hecho: Fanego 2010, au fait, de fait, en fait: D'Hondt 2014). Finally, recent studies address the interlinguistic perspective: Defour et al. 2010; Simon-Vandenbergen \& Willems 2011 (FrenchEnglish), Fraser \& Malamud-Makowski 1996 (English-Spanish), Usonienè et al. 2015 (English-Lithuanian), Lamiroy \& Vanderbauwhede 2016 (French-Dutch) or Rossari, Ricci \& Wandel 2018 (French-Italian-German).

The papers that diachronically discuss the Fr. de fait, en fait or the Engl. in fact highlight a three-stage evolution, in which the adverbial phrase moves from being an internal adverb to being a sentential adverb and, finally, a DM, with a wider scope aiming at a three-element sequence: $\langle\mathrm{S} 1-\mathrm{DM}+\mathrm{S} 2\rangle$. This study follows in the footsteps of previous similar analyses and aims to determine to what extent we could talk about a fourth stage in the evolution of the Romanian form de fapt. The next section reviews the stages of the cline proposed by Traugott, which is also an opportunity to discuss some terminological concepts; the third section is a diachronic analysis of the series $\hat{\imath}$ faptă/în fapt/de fapt; the fourth section lists the values of de fapt in present-day Romanian, which allows us to deal, in the fifth section, with its particularities in press headlines. The sixth part is dedicated to the conclusions.

\section{The theoretical framework}

This research uses the term discourse marker within the meaning proposed in the works of Bruce Fraser. For this author, DMs are a class of pragmatic markers, the latter being identified as linguistic signals related to "non-propositional part of sentence meaning" and "linguistically encoded clues which signal the speaker's potential communicative intentions" (Fraser 1996: 323). According to Fraser, there are four classes of pragmatic markers: basic pragmatic markers (I promise, please), commentary pragmatic markers (fortunately, frankly), discourse markers (but, and, so) and discourse structure markers (in summary; returning to my previous topic; look, now) (Fraser 2009: 295-297).

For Bruce Fraser, a specific element is a DM if it can be accepted in the sequence $\langle\mathrm{S} 1-\mathrm{DM}+\mathrm{S} 2\rangle$, where S1 and S2 are discourse segments and illocutionary acts. In order to function as a DM, the respective element must be a lexical expression, which is part of S2 but has no contribution to its meaning, and it must only point out to a specific semantic relationship between S1 and S2 (Fraser 2009: 297-299). The first condition excludes syntactic structures, prosodic features and non-verbal expressions from the category of 
DMs, the second one differentiates between DMs and ordinary conjunctions (without pragmatic value), and the third one highlights DMs' role as textual deictic indicating a comment about the discursive relationship between the segment that they introduce and the previous segment. Therefore, DMs have a retrospective orientation. In this respect, they differ from other pragmatic markers, such as I promise, honestly or in conclusion, which - similar to DMs - are not included in the propositional meaning but have a prospective orientation, because they qualify the $\mathrm{S} 2$ segment.

A rigorous definition of DMs is essential for our discussion. For Traugott \& Dasher (2002), for example, the existence of a prior discourse is also a requirement for defining a DM. However, these authors sometimes also include elements that do not satisfy the definition of DMs, as it can be seen from the following excerpt:

"Some $[\mathrm{DM}]$ may not require any prior discourse, or at least no obviously connected one. For example, so may be used to start a meeting, to introduce a speaker, etc. In this use it serves as an attention-getter and a signal that the speaker has something to say of import to the discourse expectations." (Traugott \& Dasher 2002: 156)

The distinction between DMs, which imply a prior discourse towards which they are oriented, and other pragmatic markers is necessary because the stake of this study is to highlight the evolution of de fapt, for which, in modern Romanian, there is evidence of a transition from the category of DMs to that of discourse structure markers (DSM) (similar to Engl. so, which functions both as a DM and as a DSM).

Elizabeth Closs Traugott discusses, in several papers, the hypothesis of a regular semantic change, which takes place "not only in well-known domains such as space > time, deontic > epistemic, but also in other domains like manner or spatial adverbial > discourse marker" (Traugott 1999: 178). These show "an overwhelming tendency [...] to develop from clause-internal or 'predicate adverbs' to sentential adverbs, and ultimately to discourse markers or "connecting adverbs"” (Traugott \& Dasher 2002: 153).

This above-mentioned evolution is a three-stage one, where the last stage is that of DMs, i.e. an element characterised by "syntactic autonomy, wide scope, semantic differentiation and, finally, by a prosodic separation from the rest of the phrase" (D'Hondt 2014: 237). DMs "signal an aspect of the speaker's rhetorical stance toward what he or she is saying, or toward the addressee's role in the discourse situation" (Traugott \& Dasher 2002: 152). That is, they function on an (inter)subjectivity scale, expressing either the degree of commitment of the speaker to his/her own utterance, or the relations between the participants to the verbal exchange. In the first case, they "index speaker attitude or viewpoint (subjectivity), [in the second one], speaker's attention to addressee self-image (intersubjectivity)" (Traugott 2010: 32). Grammaticalization goes hand in hand with subjectification ${ }^{1}$, which means that "meanings tend to shift toward greater subjectivity, that is, they become increasingly associated with speaker attitude, especially metatextual attitude toward discourse flow." (Traugott 1997: 2).

This study focuses on the use of de fapt in certain press headlines and tries to establish whether or not it behaves so as to justify being positioned at a subsequent stage in Elizabeth Traugott's scheme, i.e. the stage de fapt 4 . This means, from our point of view, that we should first ask ourselves what features should be expected from de fapt in order to justify it being positioned at this new stage. To answer this question, we should, among other things, review all the three development stages the Rom. de fapt has gone through

1 "Neither subjectification nor intersubjectification entails grammaticalization. [...] Nevertheless, there is a strong correlation between grammaticalization and subjectification, and a weaker one between grammaticalization and intersubjectification." (Traugott 2010: 38) 
so far. The research splits at this point: this chapter focuses on a theoretical discussion of these stages as an opportunity to go through the terminology and the defining features of each stage, while chapter 3 presents the diachronic perspective, with examples from different corpora.

The Romanian DMs subsumed to the DE FAPT ${ }^{2}$ type (în faptă, in fapt, de faptă, de fapt, cu faptul) are loan translations of the French corresponding expressions (dans le fait, en fait, de fait, par le fait, en effet, le fait est que). The nouns used in Romanian phrases are fapt (< Lat. factum) and faptă (< Lat. facta) $)^{3}$. Thus, fapt 'fact' and faptă 'deed' represent the starting point in the development of the structure we investigate.

\section{STAGE 0}

faptă $\breve{f}_{0}$ fapt $t_{0}$ - nouns, syntactic constituents of some prepositional phrases, freely occurring with different prepositions. In this type of contexts, fapt/faptă display the following syntactic features: it can get determiners - a definite article as an enclitic determiner and inflectional marker (1), an (implicit) demonstrative determiner (2) or it could be interpreted as a plural $(3-4)^{4}$ :

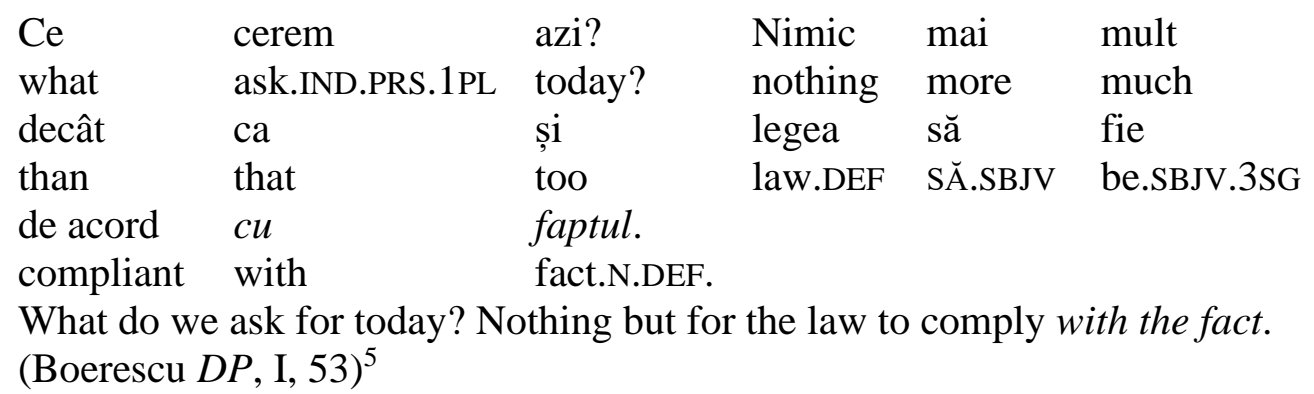

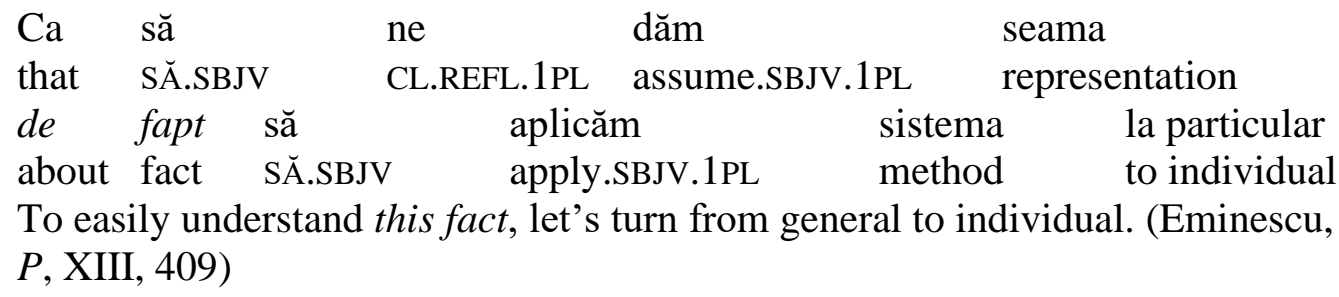

2 DE FAPT stands here for the whole series of Romanian expressions with the same meaning and similar evolution: în faptă, în fapt, de fapt. The other two, cu faptul and de faptă, stopped at the first stage of development.

$3 \quad$ Lat. facta is the plural of Lat. factum. In the oldest Romanian texts faptă does not display plural morphological features. It only occurs as a feminine singular noun (DA, under faptă).

$4 \quad$ I have introduced interlinear glosses (following the Leipzig interlinear glossing rules, available at https://www.eva.mpg.de/lingua/pdf/Glossing-Rules.pdf) for all shorter examples, where the sequences in faptă, in fapt and de fapt go through the first 3 stages of their evolution. I have only partially glossed the longer examples (where the glossed segment is highlighted in italics, and the gloss appears in brackets). However, I have left the very long examples unglossed, because glossing morpheme-by-morpheme is almost irrelevant for a study in the field of pragmatics. For example, in this study, what is important is the relation in terms of meaning that the discourse marker de fapt creates between the discourse segment that precedes it and the discourse segment that follows it, and not the morpheme analysis of the text itself.

$5 \quad$ Our italics throughout the text, except where we indicate otherwise. 
(3) Dacă până aci ne-am bazat pe credințe, acum ne bazăm pe fapt (CL.REFL.1PL rely.IND.PRS.1PL on fact) și sperăm că cei ce au dat asemeni ordine vor ști a le executa.

While so far we have relied on beliefs, now we rely on actual facts and we hope that those who have given such orders will also know how to execute them. (Eminescu, $P$, XIII, 213)

(4)

$\begin{array}{lllll}\text { voiu } & \text { să } & \text { adeverez } & \text { in faptă } & \text { că } \\ \text { want.IND.PRS.1SG } & \text { SĂ.SBJV } & \text { confirm. SBJV.1SG } & \text { in deed.F.SG } & \text { that } \\ \text { nu-s } & \text { fricos } & & \\ \text { not=be.IND.PRS.1SG } & \text { fearful } & \\ \text { I want my deeds to prove that I'm not fearful. (Codru-Drăgușanu, } P T, 122)\end{array}$

\section{STAGE 1}

DE FAPT $_{1}$ - at this stage, the lexicalization of some of the prepositional phrases from stage 0 occurs, which entails the grammaticalization of the structures as adjectival and adverbial expressions. ${ }^{6}$ These expressions still have conceptual meaning. They enter into oppositional pairs with expressions like de drept (Engl. by right, de jure) or legal (Engl. legally). Syntactically, these expressions are NP or VP adjuncts, and semantically, they take scope over the phrase. Stages 0 and 1 are parallel and synchronous variations:

(5)

$\begin{array}{lllll}\text { Frate } & \text { voi } & \text { aveți } & \text { libertatea } & \text { în faptă } \\ \text { brother } & \text { you } & \text { have.IND.PRS.2PL } & \text { liberty } & \text { in fact.ADV } \\ \text { și } & \text { noi } & \text { de nume. } & & \\ \text { and } & \text { we } & \text { in name.ADV } & & \end{array}$

Brother, you enjoy liberty as a matter of fact, we only enjoy it in theory. (CodruDrăgușanu, $P T, 139$ )

(6) Iacă dar legea eludată in faptă

here then law.DEF circumvent.PTCP.AGR in fact.ADV

So, the law is actually being circumvented. (Boerescu DP, $I, 50$ )

(7)

$\begin{array}{llll}\text { Sfatul } & \text { mi } & \text { se } & \text { dete } \\ \text { advice.DEF } & \text { CL.DAT.1SG } & \text { CL.REFL.PASS } & \text { give.IND.PS.3SG } \\ \text { cam } & \text { târziu } & \text { căci } & \text { încercasem } \\ \text { quite } & \text { late } & \text { because } & \text { experience.IND.PLUPERF.1SG } \\ \text { lucrul } & \text { în fapt. } & & \\ \text { thing.DEF } & \text { in fact.ADV } & & \end{array}$

The advice came quite late, because I had actually already done this. (CodruDrăgușanu, $P T, 126)$

Even when the other element of the pair is not lexicalized, it can be contextually inferred, as in (6), where the sequence legea ... în faptă suggests de jurelde facto pair, or in (7),

\footnotetext{
$6 \quad$ "Modern usages of au fait, de fait and en fait (Engl. in fact) are the result of a threefold process: the lexicalization of a prepositional phrase into a single functional unit entailing the grammaticalization of the three forms as adverbs, followed by a process of pragmaticalization of the adverbs as pragmatic markers." (D’Hondt 2014: 236)
} 
where the succession sfatul ... în fapt refers to the pair în vorbă/în fapt (Engl. in speech/in fact).

\section{STAGE 2}

DE FAPT 2 - at this stage, the second grammaticalization occurs: the scope of DE FAPT 2 is now the whole sentence, it functions as a sentence modifier. Schwenter \& Traugott 2000 discuss stage 2 of the Engl. in fact and notice that, as a member of the epistemic certainty expressions, it "indexes the speaker's strong commitment to the proposition, and is higher on a scale than probably and possibly, in the same way as strong epistemic must is higher on the epistemic scale than may and might" (Schwenter \& Traugott 2000: 12). A similar remark belongs to Taglicht 2001 referring to actually $y_{2}$ : the speaker who uses it in a certain utterance "is envisaging a scale of properties with the content of that phrase at the top, and implying that any property below it on the scale would make the expression too weak" (Taglicht 2001: 2). For Traugott 1999, the responsibility of phrasing the utterance preceding DE FAPT 2 belongs to the speaker. Thus, the speaker signals a contrast either a) with the previous utterance, which refers to an objective reality, and to the expectations of the listener/reader related to it, or b) with the expectations that the speaker creates. The speaker's commitment to the content of the sentence does not change, but the way in which this content is expressed significantly differs in the two situations above.

The following examples underline the first case: what is obvious here is the speaker's/narrator's commitment to the content of the utterance including $\hat{\imath}$ fapt $f_{2}$ or $\hat{i n}$ faptă $\breve{2}_{2}$. It is also obvious that the reader's expectations after the first sentence/verse are contradicted by the speaker/narrator in the second sentence/verse:

(8) Ea [casa de amortizare] funcționă astfel mult timp și se bucură de mare credit. Dar în fapt nu-și indeplini scopul (but in fact.ADV not=CL.DAT.3SG fulfil.IND.PS purpose.DEF); căci datorii mai mari și mai grele se adăogau peste cele vechi.

It [the amortization house] has been working like this for a long time, enjoying a great deal of credit. But in fact it failed to fulfil its purpose; for greater and heavier debts have been added to the old ones. (Boerescu, DP, II, 238)

(9) Pentru că era din fire cam p-o 'reche, nezdravan, Nu-1 găsești însă în faptă să fi fost vreun viclean.

$\begin{array}{lllll}\text { nu-1 } & \text { găsești } & \text { însă } & \text { în faptă } & \\ \text { not=CL.ACC.3SG } & \text { find.IND.PRS.2SG } & \text { however } & \text { in fact.ADV } & \\ \text { să } & \text { fi } & \text { fost } & \text { vreun } & \text { viclean } \\ \text { SĂ.SBJV } & \text { be.AUX } & \text { be.PTCP } & \text { some } & \text { trickster }\end{array}$

Because he was kind of a reckless, madcap guy

But his deeds don't prove him to have been a trickster. (Pann, NH, 204)

The difference between the use of these adverbs as sentence modifiers and their use as stage- 1 adverbs, in which the scope of the adverb is restricted to the syntactic group that it belongs to, can be clearly seen when used simultaneously in the sentence: "but, in fapt 2 (i.e. 'in reality') the house of amortization failed to fulfil its $\hat{i n} f_{a p t} t_{1}$ purpose (i.e. 'the real/initial purpose')"; "he doesn't prove in faptă ${ }_{2}$ ('in reality') to have been a in faptă trickster (i.e. 'a real/true-born trickster')". The examples above have been intendedly 
phrased in this particular way, but they have not been highlighted, and their degree of subjectivity is more vague than in (10) below.

In the second group of examples, the speaker is more subjectively involved. In this case, (s)he "sets up false scenarios and then shows that the assumptions manifest in them are wrong, inappropriate to the occasion, etc." (Traugott 1999: 183). The evolution towards stage 2 implies a subjectification process, because "the development of the EA [epistemic adverb] meanings of indeed, in fact, and actually is in each case an example of subjectification" (Traugott \& Dasher 2002: 174). The false scenario that Traugott talks about involves a counter-expectation, which is a "rhetorical strategy", as noticed by the quoted author (Traugott 1999: 178). It "is a matter of point of view and is therefore an example of the subjectivity of language" (Traugott 1999: 179). Example (10) is a typical case of constructing a counter-expectation:

(10) Atunci, dacă un quadrilater nu este nici quadrat, nici ,dreptunghiu” (sau mai bine oblong), nici „paralelogram” (sau mai bine romboid), nici romb, ar trebui să nu poată fi alta decât trapez. In fapt însă mai poate fi alta (in fact.ADV however also can be.INF another) adecă o figură planimetrică închisă în patru laturi fără nici un paralelism [Maiorescu's italics]; un asemenea quadrilater se numește trapezoid $[\ldots]$.

Then, if a quadrilateral is neither a square, nor a 'rectangle' (or rather oblong), nor a 'parallelogram' (or better a rhomboid), nor a rhombus, it can only be a trapezium. But, in fact, it could also be something else, i.e. a four-sided planimetric shape without any parallelism; such a quadrilateral is called a trapezoid [...]. (Maiorescu, $L, 33$ )

The epistemic value of in fapt is obvious in (10): în fapt, însă, mai este una (= 'for sure, there is another one'). In his example, the author conveys the contrast differently: he lists all types of quadrilaterals and he eliminates, one by one, those whose opposite sides are parallel (square, rectangle, parallelogram, rhombus), retaining (apparently after having exhausted all possibilities) the quadrilateral with only two parallel opposite sides, i.e. the trapezium. This staging is intended to highlight (as the emphasis in italics shows) the fact that we would be wrong to judge things in this way, because we might miss a possibility that we would not have thought of (but which exists objectively), i.e. a quadrilateral in which there is no parallelism between the pairs of sides that make it up. Those to whom this lesson is addressed may know very well, from geometry classes, that such a figure exists but the author assumes that they do not.

Usages based on counter-expectation have a certain degree of subjectivity, lower in (8) and (9) and higher in (10). As pragmaticalization is in close relation with subjectivisation, we can talk here about the beginning of the process of pragmaticalization.

\section{STAGE 3}

$\mathrm{DE} \mathrm{FAPT}_{3}$ - contrastive DM. The scope of this type of DM is a more complex structure than the clausal adverbs, namely $<\mathrm{S} 1-\mathrm{DM}+\mathrm{S} 2>$. The process of pragmaticalization started at the previous stage continues: the subjective dimension of de fapt 3 is stronger, emphasizing the speaker's perspective over the events ${ }^{7}$. Stage 3 implies an even greater

7 Pragmaticalization is a process during which a certain unit undergoes formal (phonological, morphological, syntactic) and semantic changes (see, for example, Dostie 2004: $35-37$, for a review of the principles of pragmaticalization). However, our study focuses mainly 
degree of subjectification, because the DM signals that the upcoming utterance is a stronger argument (on the rhetorical scale, Schwenter and Traugott 2000: 12) than the one preceding it. While DE FAPT 2 "combines aspects of the meaning of strongly epistemic adverbs like certainly and adversative adverbs like however", the lexical field to which DE FAPT 3 belongs "consists of such discourse markers as what's more, indeed." (Schwenter and Traugott 2000: 11, 12).

DMs are frequently used in polemical communicative situations, where the speaker replies to an interlocutor's speech, which the former alludes to or recalls in his own speech:

(11) [explicațiile domnului ministru al instrucțiunii publice] m-au întărit încă mai mult în convicțiunea ce am, că d-sa a fost prea indulgente pentru abaterile săvârșite de către profesorii Universităței din Iași, indulgență care a avut drept resultat că Universitatea din Iași, de fapt, nu mai esistă! (University from Iași in fact.DM not longer exist.IND.PRS.3SG).

[the explanations of the Minister of Public Instruction] confirmed once again my conviction that he was too lenient with respect to the errors committed by the professors of the University of Iași, leniency that led, in fact, to the University of Iași no longer existing. (Kogălniceanu, $C U, 23$ )

In a speech given before the Senate in 1877, Kogălniceanu discusses the case of the University of Iași, whose professors "from 1868 to this day [...] have left their chairs to become deputies, senators, engineers, diplomatic agents, etc., and $\mathrm{Mr}$. N. Ionescu [Minister of Public Instruction] has always supported them." (Kogălniceanu, $C U, 5$ ). This disregard of the teaching activity has as a direct result the fact that the students no longer attend their classes. Example (11) can be rewritten as follows: "I thank the Minister for his report on the activity of the University of Iași. In fact, the University of Iași no longer exists". The situation that the speaker refers to does not confirm the historical reality (since its establishment in 1860, the University of Iași has never ceased to exist, neither de facto nor de jure), but belongs to the rhetorical and subjective order of the discourse (confirmed once again my conviction is a subjectification discourse constituent).

\section{STAGE 4}

$\mathrm{DE} \mathrm{FAPT}_{4}$ - If de fapt $_{3}$ is a DM and differs from de fapt $t_{2}$, which is not yet a DM, it also differs from de fapt $t_{4}$, which is no longer a DM. De fapt 4 belongs to another class of pragmatic markers, illustrating a step forward in terms of rhetorical use, and it displays a higher degree of (inter)subjectivity compared to the previous stage (i.e. it acquires an intersubjective value). We shall discuss the features of this type of pragmatic marker in section 5 .

on the ever deeper subjectification process that takes place during the transition from de fapt fo $_{2}$ de $\mathrm{fapt}_{3}$, and then on intersubjectification, during the transition to de fapt $t_{4}$. For D'Hondt 2014: 259-260, the fact that en fait actually acquires a pragmatic role means that "the introduction of en fait into the discourse creates a subjective dimension, emphasizing the speaker's perspective." Traugott 2010: 38 also talks about a strong correlation between grammaticalization (which, for the quoted author, also means pragmaticalization) and subjectification. 


\section{Diachronic overview}

3.1. The lexicographical recordings of the elements of the Romanian DE FAPT series, $i n$ faptălîn fapt/cu faptul/de faptălde fapt begin in ECR (1931). It only mentions de fapt, which receives three synonyms (,în realitate, aievea, efectiv", Engl. 'in reality, as a matter of fact, in practice'); however, it does not specify its morphological nature, it does not provide examples of usages and it does not offer a different etymology from the entry word (fapt < Lat. factum).

DA (1934) records - under fapt - cu faptul and de fapt ("phrase", without any further specifications). It says nothing about the third member of the series, in fapt, although faptă also includes the "expression" in faptă, "recently replaced by de fapt", which would have theoretically required the indication of $\hat{\imath}$ fapt under fapt. This is even more bizarre, as in Maiorescu's Logic, quoted by DA for de fapt (de fapt $t_{1}$, with a single occurrence in Maiorescu's entire work), in fapt $t_{1}$ has 6 occurrences, and in fapt $t_{2}, 15$ occurrences. In contrast, DA mentions $c u$ faptul, for which we found only one occurrence in all the works in the corpus, namely in Ghica's Scrisori către V. Alecsandri. The Fr. etymology proposed by DA for de fapt is dans le fait, en fait, par le fait, en effet and réellement; however, it does not consider the Lat. de facto, member of the de jurelde facto opposition, with legal usage, as an option, which could have occurred in the evolution of de fapt at least from a certain moment onward.

Scriban (1939) also mentions two members of the series: in fapt and de fapt; the latter is recorded only in opposition to de drept, opposition illustrated as follows:

$\begin{array}{llll}\text { Ludovic XIII } & \text { era } & \text { rege } & \text { de drept } \\ \text { Louis XIII } & \text { be.IND.IPF.3SG } & \text { king } & \text { of law.ADJ } \\ \text { dar } & \text { de fapt } & \text { era } & \text { Richelieu } \\ \text { but } & \text { of fact.ADJ } & \text { be.IND.IPF.3SG } & \text { Richelieu } \\ \text { Louis XIII was king as of right, } & \text { but the real king was Richelieu }\end{array}$

which would be equivalent to a connection, merely suggested, between the pairs de drept/de fapt and de jure/de facto). In addition, the pair rege de drept/(rege) de fapt clearly indicates that Scriban focuses only on the stage de fapt $t_{1}$ and only on its adjectival usage. None of the three dictionaries provides examples of de fapt/în fapt/în faptă used as adverbial phrases (cu faptul is only adverbial).

3.2. Therefore, the dictionaries provide incomplete and confusing information and do not even give a vague idea about the evolution of the forms discussed herein. We try to formulate some observations regarding the evolution of the Romanian forms, starting from the data provided by a corpus that covers (considering the years of their writing) the 1829-1947 period. The corpus we chose for the early $19^{\text {th }}$ century includes historical writings - the capital work of N. Bălcescu, prose - the complete work of Negruzzi, and poetry - the writings of Alecu Donici and Povestea vorbii and Năzdrăvăniile lui Nastratin Hogea by Anton Pann, which total almost 2,200 pages. For the late $19^{\text {th }}$ century, we chose several volumes of parliamentary speeches - V. Boerescu, Ion C. Brătianu, Titu Maiorescu, memories - Ion Ghica's Scrisorile către V. Alecsandri, a travel diary - I. Codru-Drăgușanu, Maiorescu's Logic and all of Eminescu's newspaper editorials, i.e. a total of 9,000 pages. Finally, for the early $20^{\text {th }}$ century we selected for our corpus: parliamentary speeches - Vintilă Brătianu, Armand Călinescu, Nicolae Iorga, a university course by G. Călinescu and a part of his editorials, i.e. 2,400 pages, which means a general total of 13,600 pages. The data provided by the corpus allow us to make observations 
related to the history of the forms subject to discussion (3.2.1.), their combinatorial availability (3.2.2.), their relation to stage 0 (3.2.3.), as well as observations about their adjectival and/or adverbial use (3.2.4.) and their distribution according to stylistic criteria (3.2.5.). A brief comparison between the evolution of the Romanian forms and that of their French counterparts (3.2.6.) is also relevant for the present discussion.

3.2.1. The oldest Romanian form is $\hat{i n}$ faptă used in the early $19^{\text {th }}$ century with adverbial value and very rarely as a DM; it is competed by in fapt, widely used in the second half of the $19^{\text {th }}$ century, with multiple occurrences for the stages $i n$ fapt $_{1}$ (mainly adverbial), in fapt $t_{2}$, but less frequent for in fapt 3 . De fapt developed in parallel in the $19^{\text {th }}$ century and it was mainly used as an adjective, rarely as an adverb and very rarely as a DM. The use of $\hat{\imath}$ fapt and de fapt radically differs in the first five decades of the $20^{\text {th }}$ century, when in fapt loses ground in favour of de fapt.

The examples prove that in faptă was used between 1800 and 1880. In our corpus, the first example in which in faptă appears as a DM dates to around 1840, in Alecu Donici's fables (example (12)). This suggests that Romanian followed a particular path of development, as the pragmaticalization of $\hat{\imath}$ faptă could be influenced neither by en fait (the first example of en fait 3 in D'Hondt's corpus is dated 1855) nor by de fait, because "so far, de fait does not seem to have developed really pragmatic uses." (D'Hondt 2014: 260):

\begin{tabular}{|c|c|c|c|c|}
\hline $\begin{array}{l}\text { Spre } \\
\text { for }\end{array}$ & $\begin{array}{l}\text { laudă } \\
\text { praise.F.SG }\end{array}$ & $\begin{array}{l}\text { deşartă } \\
\text { inane.ADJ.AGR }\end{array}$ & $\begin{array}{l}\text { mulți } \\
\text { many }\end{array}$ & $\begin{array}{l}\text { zic } \\
\text { say.IND.PRS } \\
\text {.3PL }\end{array}$ \\
\hline noi & am & lucrat & când & ei \\
\hline we & have.AUX.PRF.1PL & work.PTCP & when & they \\
\hline lucrează & în faptă & $\mathrm{ca}$ & musca & la \\
\hline $\begin{array}{l}\text { work.IND.PRS.3PL } \\
\text { arat } \\
\text { ploughing N }\end{array}$ & in fact.DM & like & fly.DEF & at \\
\hline
\end{tabular}

To praise themselves in vain

Some say: 'we've been working hard'.

But actually they are working,

As if they were a ploughing fly ${ }^{8}$. (Donici, $S, 78$ )

The form $\hat{\imath}$ fapt, frequently used between 1850 and $1900^{9}$, becomes a DM ( in fapt $_{3}$ ) around 1880. In our corpus, it is attested for the first time in Eminescu's editorial, in 1878:

(13) Lăsînd doparte acuzările de rea-credință, vorba ceea: „el dă, el țipă”, prin care Românul voiește să inducă de mai înainte pe public în eroare, prevenim numai pe confrații de la Românul de a nu ne sili să ne întoarcem la argumenta ad baculum cu cari am fost adesea nevoiți a ne servi față de acești iubitori de adevăr confraţi. In fapt însă, daca renunțăm de a întrebuința o manieră mai viguroasă de a discuta, n-o facem doar pentru că Românul ar fi încetat de a merita un tratament părintesc,

8 Donici's fable corresponds to Aesop's fable The Fly on the Wheel.

$9 \quad \hat{I n}$ fapt has never ceased to be used in Romanian, as evidenced by the examples in contemporary Romanian, where in fapt $t_{1}$ and $\hat{i n ~ f a p t}_{2}$ continue to be used especially in the legal language, and $\hat{i n ~ f a p t}_{3}$ faintly competes de fapt 3 ; during the period we refer to, in fapt in general and $\hat{i n f a p t}_{3}$ in particular recorded the highest frequency rate. 
ci pentru că ne-am săturat noi înșine de a mai îndrepta un lucru strîmb prin chiar firea lui.

Leaving aside the accusations of dishonesty according to the saying: 'he who strikes shouts the loudest', by which Românul wants to mislead the public, and we only want to prevent our fellows from Românul not force us to return to the ad baculum argument which we have often had to address to our truth-lover fellows. In fact, if we give up using a more vigorous way of conducting an argument, we do so not only because Românul would have ceased to deserve parental treatment but because we are tired of straightening by ourselves something crooked by its very nature. (Eminescu, $P, \mathrm{X}, 109)^{10}$

Finally, de fapt, used from 1850 up to this day, becomes a DM (de fapt 3 ) around 1880. In our corpus, it is first attested in Kogălniceanu's work, in 1877, example (11). The moment in fapt and de fapt reach stage 3 is subsequent to the one when the Engl. in fact becomes a DM (around 1815, Traugott \& Dasher 2002: 171, figure 4.2.), but it is comparable to the one on which the Fr. en fait acquires a pragmatic value ("in our corpus, en fait appears with an essentially pragmatic value starting with the second half of the $19^{\text {th }}$ century", D'Hondt 2014: 258).

This is the time for a necessary clarification regarding the interpretation of the forms that we examine. From a historical perspective, an example like (14) allows more than one reading:

$\begin{array}{llll}\text { (14) Dar } & \text { tu } & \text { Juju } & \text { cu } \\ \text { but } & \text { you } & \text { Juju } & \text { by } \\ \text { ce } & \text {-ntâmplare } & & \\ \text { what } & \text { accident } & & \\ \text { Ai } & \text { căpătat } & \text { favor } & \text { asupra-ți } \\ \text { have.AUX.PRF.2SG } & \text { get.PTCP } & \text { favour } & \text { on=CL.DAT.2SG } \\ \text { așa } & \text { mare? } & & \\ \text { so } & \text { big? } & \text { la } & \text { stăpân } \\ \text { Ce } & \text { slujbă } & \text { at } & \text { master } \\ \text { what } & \text { job } & & \\ & & & \\ \text { în faptă } & \text { împlinești? } & \text { fulfil.IND.PRS.2SG } & \\ \text { in fact } & \text { atât } & \text { de } & \text { mic } \\ \text { Fiind } & \text { so } & \text { of } & \text { small } \\ \text { be.GER } & \text { ce } & \text { te } & \text { bizuiești? } \\ \text { în } & \text { what } & \text { CL.REFL.2SG } & \text { trust.IND.PRS.2SG } \\ \text { on } & & \end{array}$

What about you, Juju, by what chance

Have you been bestowed upon with such big favours?

What services for the master do you indeed carry?

Being so small, what do you rely upon? (Donici, $S, 56$ )

10 Let us briefly notice that Eminescu uses only once de faptă $\breve{a}_{1}$ : Camera Ungariei [...] susține uniunea de faptă (union.DEF of fact.ADJ) - The Hungarian Chamber [...] supports the de facto union (Eminescu, $P$, IX, 262), a hapax legomenon in his five-volume editorials. 
A watch dog asks Juju, a pet dog, the reason behind the difference in treatment that he gets from his master. This question is likely to probe different levels of development of in faptă in the quoted excerpt. The present-day reader can interpret ce slujbă implinești in faptă (lit. 'what services do you indeed carry?') as a redundant periphrasis, or an emphasis on the difference between appearance and essence ('is there really a reason for such discrimination?') or a contradiction between the speaker's utterance and reality ('actually, I wonder if there are any other hidden reasons except the ones you mention'). Such examples, which allow at least two readings and are quite frequent in the writings of that time, highlight the difficulties in interpreting such fragments (and the danger of overinterpretation), but seem to sometimes capture in statu nascendi a stage-1-to-2 or stage-2-to-3 semantic change of the structures that we discuss.

3.2.2. The expressions that we examine herein display as a stage 1 specific feature an availability to form contrasting pairs (with different adjectival and adverbial phrases). In faptă $\breve{1}_{1}$ opposes to în cuget ('in thought'), în public ('publicly'), în cuvânt ('in word') or de nume ('in name'). In fapt $t_{1}$ has the widest distribution and is frequently opposed to $\hat{\imath} n$ litera legei ('legally'), în formă ('formally'), pro forma, în drept ('rightfully'), în fond ('in substance'), in vorbă ('orally'), în scris ('in writing'), la prima vedere ('at the first sight'), în principiu ('in principle'), în teorie ('theoretically') or even în realitate ('in reality'):

(15) in fapt, ca chestiune de comptabilitate, de bancă, este o conversiune, dar în realitate este o răscumpărare a unei datorii a societăței căilor ferate.

in fact, as a matter of bank accounting, it is a conversion, but in reality it is a redemption of the railway company debt. (Brătianu, AC, VI, 310)

On the other hand, de fapt $t_{1}$ opposes to in drept ('rightfully') or legitim ('legitimate') as an adjectival phrase or to oficial ('officially') or in realitate ('in reality'), as an adverbial phrase:

(16) nu numai că nu se află în realitate nici o garanție, dar se și respinge de fapt principiul inamovibilităței

not only there is no guarantee in reality, but the principle of immovability is in fact rejected (Boerescu, DP, I, 78)

The high availability of in fapt $_{1}$ and the very wide semantic range of the contrastive pairs it establishes differ strikingly from the behaviour of de fapt $t_{1}$, which enters into much fewer contrasting pairs, with more abstract terms. From another point of view, the fact that $\hat{\imath}$ fapt $_{1}$ and de fapt $t_{1}$ make contrastive pairs with in realitate (with which, theoretically, they share the same lexical micro-field) can be interpreted as an indication of an ongoing semantic change, towards stage 2.

3.2.3. Many other examples prove the connection between stage 0 and stage 1 of these forms. This relationship stands out if we go through the data in Table 1: 
Table 1. The relationship between faptă and în faptă in early $19^{\text {th }}$ century

\begin{tabular}{|c|c|c|c|c|c|c|c|}
\hline & fapt $_{0}$ & $\hat{\imath}$ fapt $_{1}$ & faptă $_{0}$ & \multicolumn{2}{|c|}{$\hat{\imath}$ faptă $_{1}$} & $\hat{\imath} n$ faptă $_{2}$ & $\hat{\imath} n$ faptă $_{3}$ \\
\hline & & & & adj. & adv. & & \\
\hline N.Bălcescu & 0 & 0 & 56 & 0 & 1 & 0 & 0 \\
\hline A.Pann & 0 & 0 & 29 & 0 & 0 & 1 & 0 \\
\hline A.Donici & 0 & 0 & 26 & 0 & 6 & 0 & 1 \\
\hline C.Negruzzi & 1 & 0 & 75 & 0 & 1 & 0 & 0 \\
\hline $\begin{array}{l}\text { A.Donici and C.Negruzzi } \\
\text { (in collaborative translations) }\end{array}$ & 2 & 0 & 34 & 0 & 3 & 0 & 0 \\
\hline TOTAL & 3 & 0 & 220 & 0 & 10 & 1 & 1 \\
\hline
\end{tabular}

The figures indicate a direct correlation between the frequency of the nouns faptă $\breve{a}_{0}$, fapt $_{0}$ and the frequency of the phrases in faptă $\breve{1}_{1}$ and $\hat{\imath}$ fapt $_{1}$. In Bălcescu, Pann and Donici, fapt has zero occurrences, and in Negruzzi and in the translations made together with Donici, this noun appears only in an idiom - faptul zilei (lit., 'the beginning of the day, dawn'). This is reflected in the absence of in fapt $t_{1}$ from the writings of the authors that we selected for the first half of the $19^{\text {th }}$ century.

3.2.4. In Romanian, the stage 1 forms are likely to be both adjectival and adverbial adjuncts. There is a clear distinction between the two types of adjuncts in terms of frequency, for each form independently, as well as compared to each other. In the first half of the $19^{\text {th }}$ century, $i n$ faptă $\breve{1}_{1}$ behaves exclusively as an adverbial adjunct. In the second part of the century, we identified 10 occurrences as an adverbial adjunct and only two as an adjectival adjunct. In fapt $t_{1}$ is used similarly, with 59 occurrences as an adverbial adjunct and with only 5 as an adjectival adjunct. Contrastingly, during the same period, de fapt $_{1}$ occurs mostly as an adjectival adjunct ( 75 occurrences) and less as an adverbial adjunct (only 13 occurrences). These figures indicate a real competition only between the adverbial expressions în faptă 1 and $\hat{\imath}$ fapt f $_{1}$, while $\hat{i n}$ fapt $_{1}$ and de fapt $_{1}$ seem to be used preferentially by the authors either as an adverb - $\hat{\imath}$ fapt $t_{1}$ (59 occurrences, compared to only 5 as an adjective), or as an adjective - de fapt $t_{1}$ (75 occurrences, compared to only 13 as an adverb), as summarised in Table 2:

Table 2. In faptă, în fapt and de fapt in late $19^{\text {th }}$ century

\begin{tabular}{|c|c|c|c|c|c|c|c|c|c|c|c|c|}
\hline & \multicolumn{2}{|c|}{ in faptă 1} & \multirow{2}{*}{$\begin{array}{c}\hat{\imath} n \\
\text { faptă } \breve{a}_{2}\end{array}$} & \multirow{2}{*}{$\begin{array}{c}\hat{i n} \\
\text { fapt } \check{a}_{3}\end{array}$} & \multicolumn{2}{|c|}{ in fapt ${ }_{1}$} & \multirow{2}{*}{$\begin{array}{c}\hat{\imath} \\
\text { fapt }_{2}\end{array}$} & \multirow{2}{*}{$\begin{array}{c}\hat{i n} \\
\text { fapt }_{3}\end{array}$} & \multicolumn{2}{|c|}{ de fapt $t_{1}$} & \multirow{2}{*}{$\begin{array}{c}d e \\
\text { fapt }_{2}\end{array}$} & \multirow{2}{*}{$\begin{array}{c}d e \\
\text { fapt }_{3}\end{array}$} \\
\hline & adj. & adv. & & & adj. & adv. & & & adj. & adv. & & \\
\hline $\begin{array}{l}\text { I.Codru- } \\
\text { Drăgușanu }\end{array}$ & 1 & 0 & 0 & 0 & 0 & 1 & 0 & 0 & 0 & 0 & 1 & 0 \\
\hline I.Ghica & 0 & 1 & 0 & 0 & 0 & 1 & 0 & 1 & 0 & 0 & 0 & 0 \\
\hline V.Boerescu & 0 & 5 & 3 & 0 & 0 & 30 & 45 & 1 & 8 & 7 & 2 & 0 \\
\hline $\begin{array}{l}\text { I.C. } \\
\text { Brătianu }\end{array}$ & 0 & 0 & 0 & 0 & 0 & 0 & 1 & 0 & 7 & 0 & 1 & 0 \\
\hline T.Maiorescu & 0 & 0 & 0 & 0 & 4 & 18 & 39 & 13 & 31 & 2 & 1 & 0 \\
\hline M.Eminescu & 1 & 4 & 9 & 21 & 1 & 9 & 10 & 1 & 29 & 4 & 2 & 1 \\
\hline TOTAL & 2 & 10 & 12 & 21 & 5 & 59 & 95 & 16 & 75 & 13 & 7 & 1 \\
\hline
\end{tabular}

The frequency of $\hat{i n} f_{a p t}$ and de fapt $_{2}$ in the late $19^{\text {th }}$ century is directly proportional to

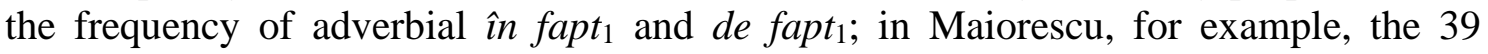
occurrences of in fapt $_{2}$ must be directly related to the large number of occurrences (18) of adverbial in fapt $t_{1}$; similarly, the almost complete absence of de fapt $_{2}$ must be correlated with the small number of adverbial occurrences of de fapt ${ }_{1}$ ( 2 occurrences in 2,873 pages of Maiorescu's work). In the writings from the early $20^{\text {th }}$ century, we witness a paradigm 
shift: în fapt $t_{2}$ and $\hat{\imath}$ faptă 2 are actually abandoned in favor of de fapt $_{2}$ - counting 46 occurrences. These must be directly connected with the more frequent use of adverbial de fapt $_{1}$ (11 occurrences), which represents the prerequisite for the appearance of de fapt 3 (20 occurrences). In the early $20^{\text {th }}$ century, following the change of generations, de fapt takes over all the tasks of in fapt, as shown in Table 3:

Table 3. In fapt and de fapt in early $20^{\text {th }}$ century

\begin{tabular}{|l|c|c|c|c|c|c|c|c|}
\hline & \multicolumn{2}{|c|}{ in fapt $_{1}$} & in fapt $_{2}$ & in fapt $_{3}$ & \multicolumn{2}{c|}{ de fapt $_{1}$} & $\begin{array}{c}\text { de } \\
\text { fapt }_{2}\end{array}$ & de fapt $_{3}$ \\
\hline & adj. & adv. & & & adj. & adv. & & \\
\hline V.Brătianu & 0 & 0 & 0 & 0 & $\mathbf{3 8}$ & $\mathbf{8}$ & $\mathbf{1 9}$ & $\mathbf{7}$ \\
\hline N.Iorga & 0 & 1 & 0 & 0 & $\mathbf{4}$ & $\mathbf{1}$ & $\mathbf{7}$ & $\mathbf{3}$ \\
\hline A.Călinescu & 3 & 12 & 3 & 0 & $\mathbf{8}$ & $\mathbf{1}$ & $\mathbf{2}$ & 0 \\
\hline G.Călinescu & 0 & 0 & 0 & 0 & $\mathbf{0}$ & $\mathbf{1}$ & $\mathbf{1 8}$ & $\mathbf{1 0}$ \\
\hline TOTAL & 3 & 13 & 3 & 0 & $\mathbf{5 0}$ & $\mathbf{1 1}$ & $\mathbf{4 6}$ & $\mathbf{2 0}$ \\
\hline
\end{tabular}

3.2.5. The distribution of $\hat{\imath}$ fapt $_{2}$ and $\hat{i n}_{\text {fapt }}$ according to discourse genres is also conspicuous. In Maiorescu's Logica, for example, in fapt $t_{1}$ counts 6 occurrences, in fapt f $_{\text {, }}$ 15 , while in fapt $t_{3}$ counts none. Maiorescu brings to the attention of his students seemingly contradicting realities, constructing counter-expectation scenarios; because Logica is a science textbook, the author operates mainly on an epistemic scale, therefore we see the extensive use of $\hat{\iota}_{n}$ fapt $_{2}$. But the use of $\hat{\imath}$ fapt $_{3}$ requires a previous speaker, as well as movements on a rhetorical scale and a consistent addition of subjectivity. Therefore, $i n$ fapt $_{3}$ is extensively displayed in parliamentary speeches and newspaper editorials, highly polemic, as it can be seen by comparing the following examples:

(17) În exemplul: toate corpurile fisice sunt grele, judecata arată corpurile fisice subordinate sferei noțiunii greu [Maiorescu's italics]. In fapt 2 , sferele acestor noțiuni sunt identice, căci viceversa nu există alt undeva greutate, decât în corpuri fisice. Dar judecata citată ca exemplu nu o arată, și nici nu are scopul de a o arăta. In the example: all physical bodies are heavy, the reasoning shows physical bodies subordinated to the scope of the notion of heavy. In fact, the scopes of these notions are identical, because weight cannot be found elsewhere, except for in physical bodies. But the reasoning cited as an example neither proves it, nor aims to prove it. (Maiorescu, $L, 53$ )

(18) [...] când vine d-sa [Petru Poni] aici în Senat și, fără a releva partea principală a tendenței unor articole propuse în proiect, le combate cu tot dinadinsul și aduce contra lor legea franceză din 1882, adecă tocmai antagonismul simţimântului religios, ce impresie poate să producă discursul d-sale în această parte a sa? Ce impresie? Vă pot dovedi, ce impresie! Vrea să zică, în fapt ${ }_{3}$, în cugetul d-sale intim, poate că onor. d. Poni este un amic al acestei tendenţe din proiectul de lege, dar nu o spune; combate proiectul fără a releva această parte care, după cât ați văzut, era de cea mai mare importanță și se cuvenea să nu fie trecută sub tăcere. [...] when he [Petru Poni] comes here to the Senate and when, without disclosing the main tendency of some draft [law] articles, he fights them with all his heart and mentions the French law of 1882 as an argument against them, i.e. precisely the antagonism of the religious sentiment, what impression can such a speech produce? What impression? I can tell you what impression! This means, in fact, that, in his deepest intimacy, honourable Mr. Poni might be a supporter of this tendency of the draft law, but he doesn't state it overtly; he fights the draft without 
mentioning this part, which, as you have seen, was the most important one and, consequently, should not have been silenced. (Maiorescu, DP, IV, 535)

The scope (in terms of discourse genres) of $\hat{i n}$ fapt $_{2}$ is therefore wider than that of the corresponding DM in fapt 3 .

3.2.6. The study of the data provided by the corpus suggests that Romanian followed its own path in the historical development of these forms, compared to French, which influenced Romanian only at the beginning of the $19^{\text {th }}$ century. French developed three concurrent and congeneric forms, au fait, de fait and en fait, attested in the $14^{\text {th }}$ century (au fait and en fait) and in the $15^{\text {th }}$ century (de fait), with a common origin (Lat. factum) and similar development, but with three different values in contemporary French. Thus, "au fait is essentially a discourse organizer [...]. The sentence introduced by au fait expresses what is missing in the previous sentence, considered crucial for the continuation of the speech" (D'Hondt 2014: 242). It is preferred in interrogative phrases and interpellations, which imply an intersubjective value. On the other hand, de fait cannot introduce a new subject, it reformulates a previous point of view and refers to a previously established fact, thus looking backward; it can be seen in non-contrastive contexts and it introduces a confirmation or a clarification. Finally, en fait has the most extensive usages of the three forms and is the most frequent one; as a sentence adverb, "en fait has an epistemic value close to en réalité and it signals a particular contrast with the immediately preceding context or with the expectations created" (D'Hondt 2014: 247). At the textual level, as a connector, "en fait introduces a contrast in the broad sense compared to the previous sentence, i.e. a construction, a specification, a redefinition or a correction of the previous sentence" (D'Hondt 2014: 248). As a contrastive DM, en fait refers to new facts, it introduces a break with regard to the prior discourse. Of the three forms, en fait went the farthest on the path of its development as a pragmatic marker, and "the pragmaticalization of en fait continues even today" (D'Hondt 2014: 260). Therefore, French displays a pattern with three congeneric forms and parallel evolution. At present, these three share in a particular way the field of pragmatic markers, each one displaying a specific usage.

The clear distinction between two of the meanings of the etymon fait: fait 2 'fact, what happened, what exists' (the content of the forms de fait and en fait) and fait 3 'the thing, the subject, the matter that it is all about' (the content of the form au fait) as well as the primary meaning of the preposition that each of these includes: $\grave{a}$ (destination orientation), $d e$ (distance from the point of origin), en (the place in itself) equally contributed to the development of three distinct types of usage for the French phrases (D'Hondt 2014: 238-239). Contrastingly, Romanian made no distinction between the semantics of fapt, and neither did it interpret differently the two nouns fapt and faptă (as it can be easily inferred from the similar and, for a short time, parallel evolution of $i n$ faptă and în fapt). Furthermore, unlike French, where the syntactic pattern involves a definite article ( $a u$, from au fait, comes from à le), Romanian did not differentiate between the syntactic patterns with a definite article ( $c u$ faptul) and those lacking a definite article (specified by different prepositions, $\hat{\imath}$ and $d e-\hat{\imath}$ fapt, de fapt) and interpreted them alike.

Therefore, French encouraged the diversity of the forms and their preferential use, while Romanian exploited the polysemy of a single form, that changed from one epoch to another: an expression evolved, fully reached (or not) its potential, then it was abandoned in favour of another form - that had been its competitor for a while - which, in its turn, displayed the same development pattern. 
An interesting distinction between the usages of en fait is made by Wandel 2017, who demonstrates that this framing adverbial has two kinds of usages in French, as "its framing scope (Fr. portée cadrative) is related either to the propositional content of the utterance or to the enunciation itself" (Wandel 2017: 5). Thus, if there are contextual indicators in $\mathrm{S} 1$ that signal a different perspective, at content level, from that existing in S2, then the framing scope of en fait is propositional. The set of contextual indicators is heterogeneous; it can include proper nouns indicating another speaker (Mr. Bertrand), evidentials (according to $X$ ), verbs of opinion (to consider, to believe, to think), adverbs referring to theory or appearance (in principle, theoretically, apparently), verbal modes or tenses expressing uncertainty (such as conditional or imperfect). In contrast, the framing scope of the discussed marker is enunciative if en fait "marks a change of perspective at the enunciative level, indicating the speaker's positioning with respect to [previous] utterances within the discourse" (Wandel 2017: 20) without such indicators in S1. In the latter case, en fait's ability to set a contrast weakens, and it may capture other values - for example, one of reformulation marker. The cited author believes that there is a correlation between the propositional/enunciative distinction and different discourse genres, in the sense that "more 'informative' genres, which do not explicitly evaluate opinions or perspectives (encyclopaedias, scientific texts, etc.), contain mostly propositional forms for structuring information and fewer enunciative forms, while the more 'argumentative', rather oral genres (political speeches, oral conversations, online verbal exchanges, etc.) need both enunciative forms to indicate the relevance of an argument and propositional forms to structure blocks of information" (Wandel 2017: 26). The evolution of Romanian forms shows that contextual indicators such as those mentioned above in 3.2.2. are characteristic for stage 1 of $\hat{\imath}$ faptă, $\hat{\imath}$ fapt and de fapt. At later stages of their evolution, the specific contrast for these discourse markers tends to be achieved through other types of indicators: rhetorical strategies such as the one illustrated in (10) or the achievement of a contrast between the utterances of a previous speaker, rendered in Direct discourse, as in (11), Indirect discourse, as in (25), or Narratted discourse, as in (12) and (26), and the statements of the actual speaker, contained in S2. Finally, enunciative usages of de fapt lose their contrastive value, as in (28)-(30). The three stages of de fapt (prepositional phrase, sentence modifier, discourse marker) are parallel and synchronous forms in current Romanian, but a study of their use in relation to the informative/argumentative distinction has not yet been made. As we have briefly shown in 3.2.5, it seems that, in Romanian, in fapt $t_{2}$ and $\hat{i n ~ f a p t ~}_{3}$ can also be differentiated according to the discourse genres in which they appear, $\hat{\imath} n$ fapt $_{2}$ being specific to informative genres, and $\hat{i n f ~ f a p t ~}_{3}$ to argumentative ones. However, this is only a hypothesis and it needs to be tested for the usages of de fapt in contemporary Romanian.

\section{The current status of the de fapt DM}

The Romanian DM de fapt fulfils a contrastive function. All the other values revolve around it and are influenced by it.

4.1. The core meaning of the Romanian forms is contrastive; non-contrastive usages, with which they sometimes appear, have not been established. Examples (19) and (20) witness contexts where de fapt (to mention only this one) is in fact an elaborative discourse marker. An elaborative discourse marker (Fraser 2009: 296) introduces an utterance that confirms the previous one, plays a key-role in the development of the discourse and sends to an objective reality. All these are features of the Fr. de fait (D'Hondt 2014: 244-246); 
de fapt belongs to the same semantic field as și ('and', as a DM) and, sometimes, they both appear in texts:

de fapt

(19) La Ministerul de Interne era de realisat reforma administrativă, și ne vom mândri că am înlăturat pe prefectul numărul doi, care era inutil, căci tot timpul se certa cu celălalt, pentru automobil, pentru onoarea de a figura la cutare ocazie publică. Și de fapt niciodată n-au funcționat doi: ori a funcționat cel care nu era ales, ori a functionat cel ales.

The administrative reform was to be carried out at the Ministry of Interior, and we would take pride in removing the second prefect, who was useless, because he was always arguing with the other one, either for the car or for the honour of being seen at a certain public event. And indeed, they have never worked as a team: either the one who had not been elected fulfilled the tasks, or the elected one. (Iorga, $C, 16$ )

(20) Pe de altă parte, există nevoia de a se înlătura în favoarea adevăratului muncitor intermediarii arendași, sub forma adeseori primejdioasă și dăunătoare sub care se prezintă azi la noi, și de fapt se manifestă un curent puternic de arendări la obști țărănești.

On the other hand, there is a need to favour the real workers and dismiss the intermediary tenants in the often dangerous and harmful form in which they can be seen in our country today, and indeed there is a strong trend towards peasant common property tenancies. (Brătianu, SC, II, 60)

Today, de fapt plays a weak role in confirming a prior statement and in preparing a discourse; its occurrence immediately induces a contrastive interpretation, even if there is no contrast in the fragment, as in the following example:

(21) Astfel încât, țineți minte, atunci când vorbim de ambivalență vorbim, de fapt, despre ceva în ființa noastră care-și dorește două lucruri opuse.

So, remember, when we talk about ambivalence, we are actually talking about something within our being that desires two different things. (CoRoLa)

4.2. On the other hand, Romanian has developed strong contrastive DMs, to introduce an utterance in contrast with the previous one; the second sequence is frequently controversial, referring to the utterance of a prior speaker (specific features of the Fr. en fait). The value of Romanian contrastive DMs can be supported and amplified by various procedures, such as the use of the verb pare (Engl. 'seems') in (22), of the phrase in realitate (Engl. 'in reality') in (23) or the construction of the sentence including de fapt as a rhetorical interrogation (24):

\section{in faptă}

(22) După câte se vorbesc prin jurnale, Austria pare a avea o constituţie. Pare [Eminescu's italics] a avea zicem, pentru că în faptă nu există decât pentru a fi batjocorită de-o mână de evrei și de beamteri cari cârmuiesc acest complex de țări în cari nimene nu-i mulțămit. 
According to the newspapers, Austria seems to have a constitution. It seems to have one, we say, because in fact it exists only to be mocked at by a handful of Jews and civil servants who rule this country complex where no one feels satisfied. (Eminescu, $P$, IX, 254)

in fapt

(23) Apoi, după bunul simț, ne închipuim noi, de aci din țara românească, că au să fie oameni cari să meargă în târg să-și schimbe argintul lor în aur, să plătească un agiu foarte scump poate, numai pentru fericirea ca să meargă apoi la bancă spre a1 depune acolo? Mare minune! În fapt însă va fi că depunerile la bancă mai le opriți; pentru că în realitate nimeni nu va merge să cumpere aur pentru ca să-1 depuie la bancă.

Then, as for the common sense, we imagine, from here, from Wallachia, that there will be people who will go to the fair to exchange their silver for gold, to pay a very expensive fare perhaps, only for the short happiness of going to the bank to deposit it there? A true miracle! But, instead, bank deposits will stop; because in reality no one will go buy gold to deposit it in the bank. (Boerescu, DP, II, 11061107)

de fapt

(24) [Vintilă Brătianu răspunde campaniei ziarelor takiste în privința terenurilor petrolifere.] Față de o campanie atât de uimitoare, avem dreptul să punem următoarele întrebări: [...] N-au de fapt nici o valoare terenurile Statului, atât de râvnite odinioară de Standard, apoi de Disconto, de grupul Rothschild-Nobel și în sfârşit de Deutsche-Bank?

[Vintilă Brătianu responds to the journalists supporting Take Ionescu regarding the oil fields.] To such an amazing campaign, we have the right to ask the following questions: [...] Is there actually no value of the State fields, once so much coveted by Standard, then by Disconto, by the Rothschild-Nobel group and finally by Deutsche-Bank? (Brătianu, SC, I, 264)

(25) Știu, nu puteți să le spuneți românilor adevărul. Nu puteți să le spuneți acum că veți crește TVA. Că le veți tăia salariile. Că-i veți da afară. Nu puteți, pentru că vine 6 decembrie, vin alegerile, singurul lucru de care vă pasă, de fapt.

I know, you can't tell Romanians the truth. You can't tell them now that you're going to increase the VAT. That you're going to cut their salaries. That you're going to fire them. You can't, because December 6 is coming, the elections are coming, the only thing that you really care about. (Ion-Marcel Ciolacu, Cameră, November 9, 2020)

(26) Altfel, despre ce vorbim aici? Bugete, povești, cifre? Când știm că de fapt în fiecare zi omorâți nu doar economia - așa, în abstract -, ci pe românii care produc, care muncesc și care ne ajută să trecem peste criză.

Otherwise, what are we talking about here? Budgets, stories, figures? When we actually know that, every day, you are killing not only the economy - abstractly speaking - but also the Romanian producers, who work and help us get through the crisis. (Victor-Viorel Ponta, Cameră, November 9, 2020) 
4.3. In addition to its basic, contrastive function, de fapt displays in present-day Romanian a reformulation function. This manifests itself in two different ways, related to the intralocutive and the interlocutive dimension of the discourse.

In (27), the speaker uses de fapt to correct different types of errors in his own speech; the speaker notices that they are inconsistent with the extralinguistic reality:

[...] reprezentanții Poliției Române au subliniat faptul că la origini acest flagel [cazurile de copii dispăruți] are o problemă sistemică, de fapt două probleme sistemice, este vorba de sărăcia extremă și lipsa de educație.

[...] the representatives of the Romanian Police outlined that the origins of this scourge [cases of missing children] lay in one specific problem of the system, actually in two problems of the system, namely extreme poverty and lack of education. (Gheorghe-Dinu Socotar, Cameră, November 24, 2020)

In (28) and (29), the speaker actually uses de fapt to correct wordings that he considers inappropriate for the current speech situation; the use of de fapt here implies a perception of the inaccuracies related to the pragmatic aspects of the verbal interaction, such as the observance of the cooperative principle and its maxims or the politeness principle:

(28) A: bună dimineața.

B: bună dimineața.

A: CINE-i acolo.

B: de fapt $\downarrow$ 'neața horia $\downarrow$ sófia.

A: sofia $\uparrow$ tu $\uparrow$

A: good morning.

B: good morning.

A: WHO is there.

B: actually $\downarrow$ 'morning horia $\downarrow$ sófia.

A: sofía $\uparrow$ you $\uparrow$ (IVLRA: 239)

(29) B: bă mă bucur vreau să te mai văd și io $\downarrow$ să mai vorbim $\downarrow$ că poate mergem $\perp$ de fapt trebuie sigur să mergem într-o: $\perp$ într-un /uichend/ în /plentărs/ sau în /CUA:ndo/

B: Dude, I'm glad I want to see you again and talk some more $\downarrow$ that maybe we can go $\perp$ in fact we really have to go in $\mathrm{a} \perp$ in a weekend /in plentărs/ or in/CUA:ndo/ (IVLRA: 177)

In (28), Sofia, a TV viewer, talks by phone to Horia Brenciu, the presenter of the morning show "Neața; after greeting him, she realizes that only "good morning" is not appropriate for that communicative context, because she had been on the show before. On a scale of intimacy with the other person (people who do not know each other $\rightarrow$ acquaintances $\rightarrow$ friends $\rightarrow$ close friends), her initial greeting is appropriate for the first step of the scale, but not for the second, where a greeting should be accompanied by the first name of the interlocutor. In (29), the speaker expresses his desire to meet his interlocutor, but realizes that the modal poate ('maybe') he had just used is too weak, so he restates the proposal, using the sequence trebuie sigur (lit. 'must for sure'), showing a higher interest in the interlocutor and at the same time signalling to the latter that he himself can advance a more precise date for the meeting. In such cases, de fapt seems to fulfil a function similar 
to elaborative DMs, since it develops and improves an intervention, in terms of pragmatic discourse reality.

4.4. De fapt can actually acquire values that belong to other classes of pragmatic markers, such as topic orientation markers (Fraser 2009: 297) as in (30), where de fapt, in the context of the structure [voiam ('I wanted') + declarative verb], introduces a new subject into the discourse:

(30) Brrrrrrrr... Ce? Frig? Nici vorbă! Noi voiam de fapt să vă recomandăm o ciabatta cu brânză, cu multă brânză.

Brrrrrrr ... What? Cold? No way! We actually wanted to recommend you a cheese ciabatta with extra cheese. (Enjoy, Facebook page, October 5, 2018)

\section{De fapt - attention marker}

At this stage of development, we are interested in all those cases that can no longer be subsumed to the de fapt 3 specific structure $<\mathrm{S} 1-\mathrm{DM}+\mathrm{S} 2\rangle$. These new functions, specific to the de fapt $_{4}$ stage, are gradually reached, and start from the de fapt 3 contrastive DM. Consider the fragment:

Stop suffocating us with these absurd and totally unethical and illegal questions about the human administration of animal drugs and stop depleting our animal ivermectin stock because of your self-administration! (veterinarian Ovidiu Roşu, on his Facebook page)

To give this FB post a proper title, the journalist concisely summarizes the above statement: Ivermectin is an antiparasitic intended strictly for animal use, an utterance that is the representation in the Narrated Discourse ${ }^{11}$ (or, more precisely, Narrated Writing) of the above fragment. At the same time, this excerpt shows both the veterinarian's commitment towards the statement "ivermectin is for veterinary purposes only" (which can be explained by introducing this statement though an opinion verb - I consider/believelam convinced that $X$ ), and his opposition to the contrary belief ("ivermectin is also for human use"). The journalist equates the epistemic commitment and the fight against the opposite belief through de fapt. By using this DM he both endorses the opinion of the source and he presents this opinion as the only valid one. The result of the whole process will be as follows:

(31) Ivermectina este, de fapt, un antiparazitar destinat strict animalelor

Ivermectin is, in fact, an antiparasitic for animal use only (Adevărul, January 26, 2021)

Therefore, de fapt belongs to the source (veterinarian Ovidiu Roşu), insofar as it is a Narrated Attitude, i.e. a means of representing a textually manifested state of mind

11 "I will call 'Narrated Discourse' a reference to an enunciative event, without mention of its precise content by way of a completive or an infinitival clause (unlike Indirect Discourse). [...] As with other S\&TP [Speech and Thought Presentation] categories, I will distinguish between Narrated Speech, Narrated Thought, Narrated Attitude and Narrated Writing." (Marnette 2005: 85) 
through the speaker's firm commitment towards his own statements and by opposition to the contrary opinion. De fapt belongs to the journalist as well, insofar as it is a formula by which the statement and attitude of the source are rhetorically enhanced: de fapt endorses the opinion of the source and thus becomes, from an opinion that the journalist legitimises, the only one that can be maintained.

5.1. There are two types of de fapt 4 . The first of these is reached by blurring $\mathrm{S} 1$ (the contrasting discourse). This blurring is also a consequence of the fact that the press article where de fapt 4 occurs belong to a serial discourse. A serial discourse occurs when there is a sequence of same topic discourses, which may or may not belong to the same author. Specific to serial discourses are, on the one hand, the possibility for each of their elements to refer to any of the other elements, with no specific requirement to specify the serial element that they refer to, and, on the other hand, the fact that any element of the series can reflect and influence the way the reader interprets the facts. The headlines below illustrate a serial discourse:

(32) Bombă în cazul Caracal! Ce s-a întâmplat, de fapt, cu Alexandra și Luiza: Monstrul Dincă a mărturisit totul

Caracal case bombshell! What has actually happened to Alexandra and Luiza: the monster Dincă confessed everything (Voxbiz, January 10, 2020)

(33) Cazul Caracal. Momente de coșmar pentru Gheorghe Dincă. Ce se întâmplă, de fapt, în spatele gratiilor

The Caracal case. Nightmare for Gheorghe Dincă. What is actually happening behind the bars (Playtech, March 15, 2020)

(34) Cazul Caracal. Dezvăluiri șocante de la familia Luizei despre ce ar fi făcut, de fapt, Alexandru Cumpănașu

The Caracal case. Shocking revelations made by Luiza's family about what Alexandru Cumpănașu has actually done (Impact, August 4, 2020)

(35) Gata, a explodat bomba în cazul Caracal! Dincă a recunoscut totul! Unde e, de fapt, Alexandra

That's it, the bombshell finally exploded in the Caracal case! Dincă admitted everything! Where is, in fact, Alexandra (Capital, September 30, 2020)

In the press articles headed by the above titles, the reference to a prior discourse is fuzzy, and consequently, the contrastive DM value of de fapt is altered. The process can go one step further, to blurring the source. One common procedure is the weasel word. Weasel words (or anonymous authority) are words and phrases that someone uses to create the impression of a relevant or topical discourse about a certain subject, when, in fact, they make ambiguous and unsupported statements. Weasel words are lexical composites such as: se știe că ('it is known that'), există și opinia că ('there is also the opinion that'), au fost formulate unele critici în legătură cu ('criticism has been made regarding') etc. For example, the title of a press article in Impact is the following:

(36) Ce înseamnă, de fapt, când visezi că îţi cad dinţii

What does it actually mean when you dream that your teeth are falling out (Impact, April 10, 2021) 
De fapt contradicts an opinion not explicitly mentioned within the article and the point of view of the source (also absent) is introduced by anonymous authorities:

It is said that if you pay attention to dreams [...] they can be used as a kind of portal for your subconscious.

Some say that if you dream that you are losing your teeth, you are suffering from anxiety.

Experts say that dreams in which our teeth fall out are among the most common.

According to studies on dream interpretation, tooth loss is associated with depression.

Under these conditions, the content of the title where de fapt occurs is, in its turn, an anonymous authority. De fapt in the headline makes the reader suppose that (s)he will find within the press article both references to the contrasting previous discourse and to the opinion of the source that the author endorses. These presumptions, triggered by a DM's procedural meaning, are not valid in this context, because de fapt $t_{4}$ is not a contrastive DM. The procedural meaning of de fapt $t_{4}$ differs from de fapt 3 - it functions as an attention marker.

In (32)-(36), de fapt displays a rhetorical component in which refutatio vs captatio movements are equally distinguishable. The first suggests that all other information sources hide the truth while only the latter promises to reveal the truth in that article. None of them is actually true: in the first case, refutatio refers to a fuzzy set (the incriminated discourses create a diffuse background), in the second case, the promise is based on a third party's discourse - the source - which is also vague, as the use of anonymous authorities indicates. De fapt ${ }_{4}$ displays a higher degree of intersubjectivity than $\mathrm{de} \mathrm{fapt}_{3}$, because it conveys both the controversy (refutatio, the attitude towards the "other" discourse and its evaluation), and the invitation to read it (captatio, the relationship with the reader).

5.2. The second use of de fapt 4 implies neither a prior discourse, nor an attitude of the source towards it. In these contexts, we deal with de fapt $t_{4}$ as a purely pragmatic, intersubjective and rhetorical marker, displaying exclusively the captatio movement (the function of capturing the reader's attention). This evolution is based on the exploitation of the reading reflexes and of the expectations of de fapt $t_{3}$ standard uses, which refers to a previous $\mathrm{S} 1$.

The pragmatic marker that we are talking about probes into the reader's reading habits ("if de fapt occurs, we assume that it refers to a previous element"), but at the same time it deceives these expectations, because the prior discourse that it seems to refer to is actually an empty slot. This use of de fapt $_{4}$ can be described as follows:

1. its occurrence in the headline creates the expectation of a revelation of the truth (in contrast with another press article, that does not reveal it); but

2. the previous discourse does not really exist; its existence is presumed from the occurrence of de fapt; thus

3. the rhetorical movement of refutatio has no object, is pointless and emphatic, and

4. what remains and matters is only the intersubjective movement of captatio.

5.3. De fapt $_{4}$ develops into an attention marker, added to the press article title which is the result of a discursive summing up process. Here, de fapt does not contribute to the textual coherence and/or cohesion but it only catches the reader's attention with the 
promise of an unprecedented revelation. There are at least three distinctions between de fapt $_{3}$ and de fapt $_{4}$. We compare the way in which de fapt ${ }_{3}$ actually embeds S1 and S2 into its definition, $<\mathrm{S} 1-\mathrm{DM}+\mathrm{S} 2>$ :

1. the retroactive effect of a DM. De fapt 3 introduces $S 2$, but refers to $S 1$ - this feature was noticed, among others, by Fraser 1999: 942 and Rossari 1990: 346, who mentions "the retroactive effect" of DMs. Conversely, de fapt 4 refers to a single discourse, $\mathrm{S}$ (discourse of the source):

Cristina Ciobănașu și Vlad Gherman au spus de ce s-au despărțit, de fapt. Care e motivul real

Cristina Ciobănașu and Vlad Gherman revealed why they actually broke up. What is the real reason between this (Fanatik, February 11, 2021)

[from the body of the article: "The first day of February arrived with some sad news for the fans of Cristina Ciobănașu and Vlad Gherman. The two actors announced their separation in a six-minute social media video, due to the fact that they evolved differently and no longer shared the same future prospects."]

In (37), the headline only refers to the announcement made by the former couple (the title is hence the Narrated Speech of the announcement). Its role of creating a contrast with a previous discourse with a similar topic is null, because there is no such press article. In (37) de fapt does not function as a Narrated Attitude, because it is not significant for the way in which the source - Cristina Ciobănaşu and Vlad Gherman - relates to a previous discourse. This means that de fapt is no longer an amalgam, as in (31), and the journalist is the only one responsible for the occurrence of de fapt in the headline.

The following objections could be made to what has been previously argued: the couple's separation was likely to happen and the reasons behind this were subject to disputes and discussions among their fans; or, this title is likely to contrast with an encyclopaedic content that the journalist implies to be sharing with his reader, content that functions here as a $\mathrm{S} 1$. We must keep in mind that these reading presumptions are exactly what the journalist had expected, and their trigger is part of de fapt $t_{4}$ use strategy. This situation is characterized by the fact that a presumption of the pre-existence of a S1 is triggered by de fapt. The title implicitly promises to solve the contrast between an inferred S1 and S2 (opinion of the source), but the press article never fulfils this promise.

2. the time distance between $\mathrm{S} 1$ and $\mathrm{S} 2$. The formula $\langle\mathrm{S} 1-\mathrm{DM}+\mathrm{S} 2\rangle$ implies a time span between the two segments related by a DM. However, this does not happen in the case of de fapt 4 . In (38), de fapt 4 does not refer to a prior discourse because it cannot do so: the piece of "news" is so recent that there was no time for competing news to come up:

(38) $\mathrm{Cu}$ ce femeie a petrecut Pepe aseară, de fapt. În ce ipostaze au fost surprinși cei doi

Who is the woman Pepe actually spent the evening with. What was the couple spotted doing. (Playtech, February 26, 2021)

The refutatio movement, which de fapt enables in (37) and (38), refers to a contentless slot. It is nothing more than an emphatic gesture with no addressee, because it is devoid 
of object. The two headlines rely exclusively on the effectiveness of the captatio movement.

3. the distinct semantic content of the two segments, S1 and S2, from the DM definition. The difference in meaning between the two statements to which the definition refers is essential, because starting from this point they can be contrastively related. This relationship cannot take place in (39):

(39) Ce făceau, de fapt, în Italia doi români care se dădeau drept polițiști sub acoperire What two Romanians who were pretending to be undercover police officers were actually doing in Italy (Digi24, October 25, 2019)

The article reveals that the two Romanians mentioned in the title acted deceitfully. Pretending to be a police officer is in itself a deceit. Both the article and its title convey redundant information ('in Italy, two Romanians involved in frauds were actually deceiving people'). De fapt in the title does not have the procedural meaning of a contrastive DM (does not present the news in contrast with a prior discourse).

5.4. The lack of a previous reference of $d e$ fapt $_{4}$ consequently brings forth word order peculiarities:

- de fapt 4 does not occur in an initial position (position preferred by de fapt ${ }_{3}$ );

- de fapt ${ }_{4}$ is embedded either immediately after the predicative verb: „Unde se află, de fapt, Alexandra" ("Where is, in fact, Alexandra"), or it holds the last position in the clause: „Unde se află Alexandra, de fapt" ("Where is Alexandra, in fact”), positions specific for statements with a high degree of subjectivity: "the subjectified elements tend to be positioned peripherally compared to a constituent or a clause" (Traugott 2010: 41).

5.5. The difference between de fapt $_{3}$ and de fapt $_{4}$ is also underlined by the elements that they can be combined with, which more distinctively outline their semantic fields (combinations studied in Fraser 2013 and 2015). Whereas de fapt 3 shares the same semantic field with in realitate ('in reality'), de fapt $t_{4}$ belongs to a field that encompasses $s$ - $a$ aflat totul ('everything was revealed') and $X$ rupe tăcerea ('X breaks the silence'). The pragmatic marker de fapt 4 and the utterances $s$ - $a$ aflat totul and $X$ rupe tăcerea have identical implicatures: the pieces of information revealed by the press article were secret (or distorted or incomplete) in previous press articles on the same topic:

(40) Bianca Drăgușanu trăiește o mare dramă. Ce i-au făcut prietenii, de fapt. S-a aflat totul

Bianca Drăgușanu and the huge drama in her life. What her friends actually did to her. Everything is out in the open (Playtech, January 2, 2021)

(41) Pepe rupe tăcerea despre cum și-a făcut banii, de fapt: „Niciodată nu mi-a fost rușine"

Pepe breaks the silence about how he actually earned his money: "I was never ashamed" (Playtech, January 11, 2021)

Thus, (40) and (41) can be rephrased by equivalent headline utterances:

$\left(40^{\prime}\right)$ Everything that her friends did to her is out in the open.

$\left(40^{\prime \prime}\right)$ What her friends in fact did to her. 
(41') Pepe breaks the silence about how he earned his money.

$\left(41^{\prime \prime}\right)$ How Pepe in fact earned his money.

5.6. In the examples (37)-(41), de fapt ${ }_{4}$ displays an intersubjective value, because - based on the reading reflexes de fapt 3 triggers - it only aims to convince the reader to go through the press article after reading the title thereof. De fapt $t_{4}$ only highlights the text that we are invited to read. From this point of view, de fapt 4 belongs to the same class and displays the same functions as deci (they are attention markers):

(42) [în domeniul sănătăţii] e un haos tot- total eu am avut ocazia să să să să dau un eXEMplu. deci am plecat într-o dimineaţă la serviciu $\downarrow$ şi stau la potcoavă la vitan şi în SPAţiu ăla verde dintre sensurile de mers ale:\# maŞInilor $\downarrow$ e un spaţiu verde $\uparrow$ şi era un\# bătrîn $\downarrow$ căzut $\downarrow$ de dimineaţă $\downarrow$ i-a venit rău şi ă mă rog $\downarrow 1$-a(u) luat cineva cu maşina şi i-am zis HAI domle (xxx) la policinica vitan şi: UNde stai tataie.

[in the healthcare sector] total chaos - I had the opportunity to give you an eXAMple. so I went to work one morning $\downarrow$ and I live in Vitan, in the Potcoavă (horseshoe) neighbourhood and in that green space between the traffic lanes of: \# the cars $\downarrow$ it's a green space $\uparrow$ and there was an \# old man $\downarrow$ on the ground $\downarrow$ that morning $\downarrow$ he fainted and well $\downarrow$, someone gave him a ride and I told him COME sir (xxx) to the Vitan Clinic and: "WHere do you live, Pops?" (IVLRA: 31)

In (42), deci ('so, therefore') is a "narrative cue" (Hoinărescu 2009) that

"allows the speaker to indicate a long intervention that follows [...] it displays an anaphoric use as a textual deictic and it contributes to the textual coherence and to the integration of the speaker's utterance into a communicational universe, even though not explicitly evoked or described [...] the speaker underlines the fact that he took the turn in a conversation and has no intention to pass it on to his interlocutor. The pragmatic inferences that the deci operator triggers, namely the discursive continuity deriving from certain (implicit) premises, increase its perlocutionary efficiency and grant the features of a metadiscursive signal such as 'Attention!', 'I'm not done!', 'I don't want to be interrupted!'” (Hoinărescu 2009: 51)

De fapt 4 displays similar characteristics as deci. It indicates to the reader the details to be presented in the press article, it acts like a textual deictic (without being a real one) and it requires the reader's attention by an implicit promise that something worthy of attention follows. Usages as (42) obviously differ from (43), where deci is an inferential DM (Fraser 2009: 296-297):

(43) Moţiunea simplă va fi prezentată ... (Vociferări. Aplauze.) ...şi dezbătută la o dată când va fi fixată, conform regulamentelor în vigoare. (Vociferări.) Deci nu tot astăzi, domnule deputat Simonis, da? Nu astăzi.

The simple motion will be read out ... (Shouts. Applause.) ... and debated at a due time, established according to the regulations in force. (Shouts.) So not today, do you understand, Mr. Simonis? Not today. (Laurențiu-Dan Leoreanu, Cameră, April 12, 2021)

Therefore, it is no by chance that de fapt and deci developed into attention markers in Romanian. With this function, they achieve their goal of drawing attention to the 
importance of the following utterances by making the best use of the traits that they share with the corresponding DM.

Examples (37)-(41) are not isolated. Similar headlines are released daily, and de fapt has become a reliable means of catching the reader's attention and of encouraging the latter to continue reading the press article. De fapt 4 titles are frequent today in publications such as Playtech, Impact, Capital, Voxbiz or Adevărul. A Google search of de fapt in the digital archives of Playtech magazine, for example, returns 23 pages, with 330 results in recent years. The first title in Playtech in which de fapt appears as an anonymous authority can be dated back to June 13, 2011: „Apple a creat de fapt Androidul" ("Apple actually created Android"; the first line of the article contains a weasel word: "This is not a personal opinion, but I must say that I find it extremely interesting"). A similar search, performed in the Impact archives, returns 60 de fapt titles for articles published between March 27 and April 16, 2021, i.e. an average of 3 per day (for this publication only). Even if de fapt does not display the features outlined above everywhere in these titles, its frequent use ultimately determines its migration to the stage that we have discussed in this study.

The current uses of de fapt (rhetorically promoted in press headlines) and deci (frequently used in common Romanian) clearly indicate a pragmatic shift to the category of attention markers.

\section{Conclusions}

The evolution of the Romanian form de fapt, which follows exactly the three stages Elizabeth Traugott hypothesised, can provide a glimpse of what happens when the adverbs that are part of this pattern accomplish the transition from stage 3 to stage 4 .

The first relevant thing is that for the description of de fapt 4 the DM general scheme $<\mathrm{S} 1-\mathrm{DM}+\mathrm{S} 2>$ can no longer be used. Thus, the pragmatic mark de fapt ${ }_{4}$ loses a common feature of the previous stages, namely the semantic connection with a prior discourse. Consequently, the only appropriate description is S + DSM.

Through this discursive behaviour, de fapt moves onto a new category of pragmatic markers, that of discourse structure markers, a category that also includes iată ('look'), uite ce voiam să spun ('here's what I wanted to say'), să vezi ce s-a întâmplat ('you won't believe what has happened'), hai să-ți spun ceva ('let me tell you something') or deci ('so, therefore') in (42). The key milestones in the evolution of de fapt towards this stage are:

1. the loss of the connection with the previous discourse and its use as an anonymous authority;

2. the use of its polemic potential, inherited from the corresponding DM, which, in the case of $\mathrm{de} \mathrm{fapt}_{4}$, becomes a void rhetorical gesture (it refers to an empty slot, with a missing previous discourse);

3. the use of a reading reflex, based on the sine qua non condition of DMs: if de fapt $_{3}$ occurs, it must refer to a previous discourse. The use of de fapt $_{4}$ in a title is a promise of revealing a hidden truth, provided that the reader goes through the content of the article. The stake of this context is the invitation to read the content and not to emphasize a contrast with a previously formulated point of view, which, in the case of de fapt $t_{4}$, is just a pretext. Thus, de fapt becomes the easiest way to make a story and catch people's attention.

Therefore, at this stage, the journalist-reader relationship plays a key role. In other words, de fapt $_{4}$ acquires, for the first time ever, an intersubjective nature. 
The frequency with which de fapt is used as an attention marker in press articles is likely to indicate either a successful recipe or its ending productivity. The answer can only be given following a more thorough research, in which we should compare, among other things, the number of clicks a piece of news with a de fapt headline receives as opposed to a headline where de fapt is absent. Until then, we can only restate Peter Blumenthal's comment: "the phrase en fait has become a cliché for so many speakers, being used every two sentences." (Blumenthal 1996: 266).

\section{Acknowledgments}

After reading this study, my colleague Ariadna Ștefănescu had a series of comments related to its core theme and details, which have been very useful for drafting the final version thereof. I hereby warmly thank her.

\section{Corpus}

Bălcescu, $M V=$ Nicolae Bălcescu. Românii supt Mihai Voevod Viteazul. [Romanians Under the Rule of Voivode Michael The Brave] In Nicolae Bălcescu. 2017. Opere [Complete Works], tome II: 3-575. București: Fundația Națională pentru Știință și Artă.

Boerescu, DP = B(asile) Boerescu. 1910. Discursuri politice [Political Discourses] (1859-1883). 2 tomes. București: Socec.

Brad, $C=$ Victor Slăvescu (ed.). 1943. Corespondența între Ion Ionescu de la Brad și Ion Ghica, 1846-1874. [The letters exchanged by Ion Ionescu de la Brad and Ion Ghica] București: Imprimeria Națională.

Brătianu, AC = Ion C. Brătianu. 1932/1936. Acte și cuvântări [Documents and Speeches], tome IV (1878-1879) \& VI (1880-1881). București: Cartea Românească.

Brătianu, SC = Vintilă I. C. Brătianu. 1937/1938. Scrieri și cuvântări [Writings and Speeches], tome I (1899-1906) \& II (1907-1911). București: Imprimeriile „Independența”.

Cameră/Senat $=$ the transcript of the sittings of the two Chambers of the Romanian Parliament, available for inquiries at http://www.cdep.ro/pls/steno/steno2015.cautare?leg=\&idl=1 .

Cantemir, $S=$ Antioh Cantemir. 1838. Satire și alte poetice compuneri (traduse din rusește de A. Donici și C. Negruzzi) [Satires and Other Poetic Compositions (translated from Russian by A. Donici and C. Negruzzi)]. Iassi: Tipografia lui A. Bermann.

Catargiu, DP = Barbu Katargiu. 1914. Discursuri parlamentare [Parliamentary Speeches] (1859_ 1862). București: Minerva.

Călinescu, DP = Armand Călinescu. 1938. Discursuri parlamentare [Parliamentary Speeches], tome I (1926-1933) \& II (1934-1937). București: Imprimeria Națională.

Călinescu, $P E=$ George Călinescu. 1974. Principii de estetică [Principles of Aesthetics]. Craiova: Scrisul Românesc.

Codru-Drăgușanu, $P T=$ Ion Codru-Drăgușanu. 1910. Călătoriile unui romîn ardelean în țară și in străinătate (1835-44) („Peregrinul transilvan”) [The Journeys of A Romanian From Transylvania Within the Country and Abroad ('The Transylvanian Pilgrim')]. Vălenii de Munte: Editura Tipografiei Societății „Neamul Românesc”.

CoRoLa $=$ Corpus computațional de referință pentru limba română contemporană [Reference Computational Corpus for Contemporary Romanian Language], https://corola.racai.ro/.

CORV = Laurenția Dascălu Jinga. 2002. Corpus de română vorbită (CORV). Eșantioane. [Spoken Romanian Corpus. Samples] București: Oscar Print.

DA = Academia Română. 1934. Dicționarul Limbii Române [The Romanian Language Dictionary, II/I, [Literele] [Letters] F-I. București: Imprimeria Națională.

Donici, $S=$ Alecu Donici. 1998. Scrieri [Writings]. Chișinău: Litera. 
ECR = Ion-Aurel Candrea \& Gheorghe Adamescu. 1931. Dicționarul Enciclopedic Ilustrat ,Cartea Românească” [The 'Cartea Românească' Illustrated Encyclopedic Dictionary]. București: Cartea Românească.

Eminescu, $P$, IX = Mihai Eminescu. 1980. Opere [Complete Works], tome IX. Publicistică [Editorials] (1870-1877). București: Editura Academiei R.S.R.

Eminescu, $P, \mathrm{X}=$ Mihai Eminescu. 1989. Opere [Complete Works], tome X. Publicistică [Editorials] (1877-1880). București: Editura Academiei R.S.R.

Eminescu, $P, \mathrm{XI}=$ Mihai Eminescu. 1984. Opere [Complete Works], tome XI. Publicistică [Editorials] (1880). București: Editura Academiei R.S.R.

Eminescu, $P, \mathrm{XII}=$ Mihai Eminescu. 1985. Opere [Complete Works], tome XII. Publicistică [Editorials] (1881). București: Editura Academiei R.S.R.

Eminescu, $P, \mathrm{XIII}=$ Mihai Eminescu. 1985. Opere [Complete Works], tome XIII. Publicistică [Editorials] (1882-1883, 1888-1889). București: Editura Academiei R.S.R.

Ghica, $O=$ Ion Ghica. 2017. Opere [Complete Works], 3 tomes. București: Editura Fundației Naționale pentru Știință și Artă.

Iorga, $D P=$ Nicolae Iorga. 1909. In era „reformelor”. Discursuri politice rostite in Camera Deputaților (1907-1909) [In the Age of 'Reforms'. Political Speeches Delivered in the Chamber of Deputies (1907-1909)]. Vălenii de Munte: Tipografia „Neamul Românesc”.

Iorga, $D=$ Nicolae Iorga. 1912. Discurs rostit în ședința Adunării Deputaților, 15 decemvrie 1912 [Speech Delivered in the Sitting of the Assembly of Deputies, 1912, December, 15,]. București: Imprimeria Statului.

Iorga, C = Nicolae Iorga. 1932. Cuvântarea de la 18 septembrie 1932 [The Speech delivered on 1932, September 18]. București: Institutul de arte grafice „Lupta” Nicolae Stroilă.

IVLRA = Liliana Ionescu-Ruxăndoiu (coord.). 2002. Interacțiunea verbală în limba română actuală. [Verbal Interaction in Present-Day Romanian Language] București: Editura Universității București.

Kogălniceanu, $C U$ = Mihail Kogălniceanu. 1877. Cestiunea Universității de Iași (1, 2 și 4 februarie 1877) [The Matter of the Iași University (1877, February 1, 2, 4)]. București: Imprimeria Statului.

Maiorescu, $L=$ Titu Maiorescu. 1894. Logica [Logic]. București: Socec.

Maiorescu, DP, I = Titu Maiorescu. 1897. Discursuri parlamentare [Parliamentary Speeches], tome 1 (1866-1876). București: Socec.

Maiorescu, DP, II = Titu Maiorescu. 1897. Discursuri parlamentare [Parliamentary Speeches], tome 2 (1876-1881). București: Socec.

Maiorescu, DP, III = Titu Maiorescu. 1899. Discursuri parlamentare [Parliamentary Speeches], tome 3 (1881-1888). București: Socec.

Maiorescu, DP, IV = Titu Maiorescu. 1904. Discursuri parlamentare [Parliamentary Speeches], tome 4 (1888-1895). București: Socec.

Maiorescu, DP, V = Titu Maiorescu. 1915. Discursuri parlamentare [Parliamentary Speeches], tome 5 (1895-1899). București: Minerva.

Negruzzi, $O=$ Constantin Negruzzi. 2009. Opere [Complete Works]. București: Fundația Națională pentru Știință și Artă.

Pann, NH = Anton Pann. 1961. Fabule și istorioare. Nezdrăvăniile lui Nastratin Hogea [Fables and Stories. The Mischiefs of Nastratin Hogea]. București: Editura pentru Literatură.

Pann, $P V=$ Anton Pann. 1936. Povestea vorbii [The Story of Speech]. Craiova: Scrisul românesc. Scriban = August Scriban. 2013 [1939]. Dicționarul Limbii Românești [The Romanian Language Dictionary]. București: Saeculum I.O.

\section{References}

Blumenthal, Peter. 1996. Le connecteur en fait. In Claude Muller (ed.), Dépendance et intégration syntaxique. Subordination, coordination, connexion, 257-269. Tübingen: Max Niemeyer Verlag. 
Bruti, Silvia. 1999. In fact and infatti: the same, similar or different. Pragmatics 9 (4): 519-533. https://doi.org/10.1075/prag.9.4.04bru

Danjou-Flaux, Nelly. 1980. A propos de de fait, en fait, en effet et effectivement. Le Français Moderne 48: 110-139.

Defour, Tine, Ulrique D'Hondt, Anne-Marie Simon-Vandenbergen \& Dominique Willems. 2010. In fact, en fait, de fait, au fait: a contrastive study of the synchronic correspondences and diachronic development of English and French cognates. Neuphilologische Mitteilungen CXI, 4: 433-463.

D'Hondt, Ulrique. 2014. Au fait, de fait et en fait: analyse de trois parcours de grammaticalisation. Revue romane 49: 235-263.

https://doi.org/10.1075/rro.49.2.03hon

Dostie, Gaétane. 2004. Pragmaticalisation et marqueurs discursifs: Analyse sémantique et traitement lexicografique. Bruxelles: De Boeck/Duculot.

https://doi.org/10.1093/ijl/ec1029

Fanego, Teresa. 2010. Paths in the development of elaborative discourse markers: Evidence from Spanish. https://www.usc-teresafanego.es/publications.html https://doi.org/10.1515/9783110226102.2.197

Forsgren, Mats. 2009. Les connecteurs de fait, en fait, en effet, effectivement: observations empiriques effectuées dans des contextes discursifs variés. Syntaxe \& Sémantique 10: 51-64. https://doi.org/10.3917/ss.010.0051

Fraser, Bruce. 1988. Types of English discourse markers. Acta Linguistica Hungarica 38: 19-33. Fraser, Bruce. 1990. An approach to discourse markers. Journal of Pragmatics 14 (3): 383-395. https://doi.org/10.1016/0378-2166(90)90096-v

Fraser, Bruce. 1996. Pragmatic markers. Pragmatics 6 (2): 322-343.

https://doi.org/10.1075/prag.6.2.03fra

Fraser, Bruce. 1999. What are discourse markers?. Journal of Pragmatics 31 (7): 931-952. https://doi.org/10.1016/s0378-2166(98)00101-5

Fraser, Bruce. 2009. An Account of Discourse Markers. International Review of Pragmatics 1: 293-320.

https://doi.org/10.1163/187730909x12538045489818

Fraser, Bruce. 2013. Combinations of Contrastive Discourse Markers in English. International Review of Pragmatics 5: 318-340.

https://doi.org/10.1163/18773109-13050209

Fraser, Bruce. 2015. The combining of Discourse Markers - A beginning. Journal of Pragmatics 86: $48-53$.

https://doi.org/10.1016/j.pragma.2015.06.007

Fraser, Bruce \& Monica Malamud-Makowski. 1996. English and Spanish contrastive discourse markers. Language Sciences 18: 863-881. https://doi.org/10.1016/s0388-0001(96)00052-6 
Hoinărescu, Liliana, 2009, „Funcții pragmatice ale conectorului deci în româna vorbită actuală” [The Pragmatic Functions of deci ('so, therefore') in Present-Day Romanian], Studii și cercetări lingvistice LX, 1, p. 45-62.

Lamiroy, Béatrice \& Gudrun Vanderbauwhede. 2016. Les marqueurs de discours en effet, en fait, de fait, en réalité et leurs équivalents en néerlandais: indices de grammaticalisation. In Laure Sarda, Denis Vigier \& Bernard Combettes (eds.). Connexion et indexation. Ces liens qui lient le texte, 195-209. Lyon: ENS Éditions.

https://doi.org/10.4000/books.enseditions.6892

Lenk, Uta. 1998. Marking discourse coherence: functions of discourse markers in spoken English. Tübingen: Narr.

Marnette, Sophie. 2005. Speech and Thought Presentation in French. Concepts and Strategies. Amsterdam/Philadelphia: John Benjamins.

https://doi.org/10.1075/pbns.133

Mladenovici Ionescu, Mihaela. 2020. Actually: The Concealed Lever. Revue Roumain de Linguistique LXV: 297-306.

Oh, Sun-Young. 2000. Actually and in fact in American English: a data-based analysis. English Language and Linguistics 4 (2): 243-268.

https://doi.org/10.1017/s1360674300000241

Rossari, Corinne. 1990. Projet pour une typologie des opérations de reformulation. Cahiers de linguistique française 11: 345-359.

Rossari, Corinne. 1992a. De l'exploitation de quelques connecteurs reformulatifs dans la gestion des articulations discursives. Pratiques: linguistique, littérature, didactique 75: 111-125.

https://doi.org/10.3406/prati.1992.1671

Rossari, Corinne. 1992b. De fait, en fait, en réalité: trois marqueurs aux emplois inclusifs. Verbum 3: 139-161.

Rossari, Corinne, Claudia Ricci \& Dennis Wandel. 2018. Introducteurs de cadres et connecteurs de reformulation: étude contrastive sur corpus. Langages 212: 51-67.

Saunier, Évelyne. 2017. Au fait, de fait, en fait: trois modes de repérage subjectif. In Gaétane Dostie, and Florence Lefeuvre (eds.), Lexique, grammaire et discours: les marqueurs discursifs, 105-126, Paris: Honoré Champion.

Savelli, Marie-Josée. 2001. En fait en français contemporain: proposition d'analyse. Recherches sur le français parlé 16: 63-82.

Schiffrin, Deborah. 1987. Discourse Markers. Cambridge: Cambridge University Press. https://doi.org/10.1017/cbo9780511611841

Schwenter, Scott \& Elizabeth Closs Traugott. 2000. Invoking scalarity. The development of in fact. Journal of Historical Pragmatics 1 (1): 7-25.

https://doi.org/10.1075/jhp.1.1.04sch

Sergo, Laura. 2015. Il connettore infatti e i suoi corrispettivi francesi: distribuzione, funzioni, uso. In Borreguero Zuloaga, Margarita \& Sonia Gómez-Jordana (eds.), Les marqueurs du discours dans les langues romanes: une approche contrastive, 105-115. Limoges: LambertLucas. 
Simon-Vandenbergen, Anne-Marie \& Dominique Willems. 2011. Crosslinguistic data as evidence in the grammaticalization debate: The case of discourse markers. Linguistics 49 (2): 333-364.

https://doi.org/10.1515/ling.2011.010

Taglicht, Josef. 2001. Actually, there's more to it than meets the eye. English Language and Linguistics 5 (1): 1-16.

https://doi.org/10.1017/s1360674301000119

Traugott, Elizabeth Closs \& Richard B. Dasher. 2002. Regularity in Semantic Change. Cambridge: Cambridge University Press.

https://doi.org/10.1017/cbo9780511486500

Traugott, Elizabeth Closs. 1982. From propositional to textual and expressive meanings; some semantic-pragmatic aspects of grammaticalization. In Winfred P. Lehmann \& Yakov Malkiel (eds.), Perspectives on Historical Linguistics, 245-271. Amsterdam: John Benjamins.

https://doi.org/10.1075/cilt.24.09clo

Traugott, Elizabeth Closs. 1989. On the Rise of Epistemic Meanings in English: An Example of Subjectification in Semantic Change. Language 65 (1): 31-55.

https://doi.org/10.2307/414841

Traugott, Elizabeth Closs. 1997. The Role of the Development of Discourse Markers in a Theory of Grammaticalization. Paper presented at the 12th International Conference on Historical Linguistics, University of Manchester, August 1995 (version of 1997). https://web.stanford.edu/ traugott/papers/discourse.pdf

Traugott, Elizabeth Closs. 1999. The Rhetoric of Counter-Expectation in Semantic Change: A Study in Subjectification. In Andreas Blank \& Peter Koch (eds.), Historical Semantics and Cognition, 177-196. Berlin/New York: Mouton de Gruyter.

https://doi.org/10.1515/9783110804195.177

Traugott, Elizabeth Closs. 2010. (Inter)subjectivity and (inter)subjectification: A reassessment. In Kristin Davidse, Lieven Vandelanotte \& Hubert Cuyckens (eds.), Subjectification, Intersubjectification and Grammaticalization, 29-74. Berlin/New York: De Gruyter Mouton. https://doi.org/10.1515/9783110226102.1.29

Usonienè, Aurelija, Audronè Šolienè \& Jolanta Šinkūnienè. 2015. Revisiting the multifunctionality of the adverbials of ACT and FACT in a cross-linguistic perspective. Nordic Journal of English Studies 14 (1): 201-231.

https://doi.org/10.35360/njes.345

Wandel, Dennis. 2017. Portée propositionnelle et portée énonciative des adverbiaux cadratifs abstraits en fait et en réalité. Discours. Revue de linguistique, psycholinguistique et informatique 21: 3-29.

https://doi.org/10.4000/discours.9384 